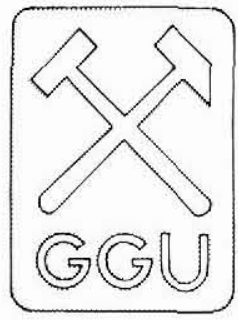

\title{
Sedimentological and stratigraphical analysis of the Upper Triassic - Lower Jurassic succession in Jameson Land, East Greenland - a summary
}

Gregers Dam

As part of ongoing studies of Mesozoic basin development and hydrocarbon potential in East Greenland, a three-year research fellowship programme was initiated in the summer of 1987 . The subject of the study was the Upper Triassic to Lower Jurassic succession in Jameson Land, East Greenland, that includes the Kap Stewart and Neill Klinter Formations (Dam, 1988, 1989). This interval has many features in common with some of the largest coeval hydrocarbon reservoirs known in the northern North Sea; the outcrops in East Greenland provide an outstanding opportunity to study details of the architecture and sedimentary history of analogues of these reservoirs. The chief aim of the project was to establish detailed and regional facies models, and special emphasis was laid on the sequence stratigraphic relationships of the sediments in order to provide predictive models of reservoir characteristics. In addition the ichnology and source-rock potential of the formations have been studied. These studies have led to the establishment of a new formal lithostratigraphic and sequence stratigraphic scheme, and the unravelling of the palaeogeographic evolution of the basin.

\section{Geological setting}

The Jameson Land basin is located at the southern end of the exposed part of the East Greenland rift system (Fig. 1) and contains a $17 \mathrm{~km}$ sedimentary succession ranging in age from Devonian to Tertiary (Christiansen et al., 1991). During the Upper Triassic Lower Jurassic the Jameson Land basin was bounded to the north by a NW-SE cross-fault in Kong Oscar Fjord, to the west by a major N-S fault and to the east by a NNE-SSW elongated landmass corresponding to the present-day Liverpool Land area (Surlyk, 1978, 1990). The southern boundary is unknown but the basin may have extended south of Scoresby Sund. The Late Triassic - Early Jurassic period in the Jameson Land basin was marked by subsidence largely controlled by thermal contraction following a long period of Late Palaeozoic rifting (Surlyk et al., 1986).
The Triassic - Early Jurassic records a long-term change from hot arid to more temperate humid climates. Lower Triassic continental red beds with subordinate carbonates and evaporites, indicating an arid

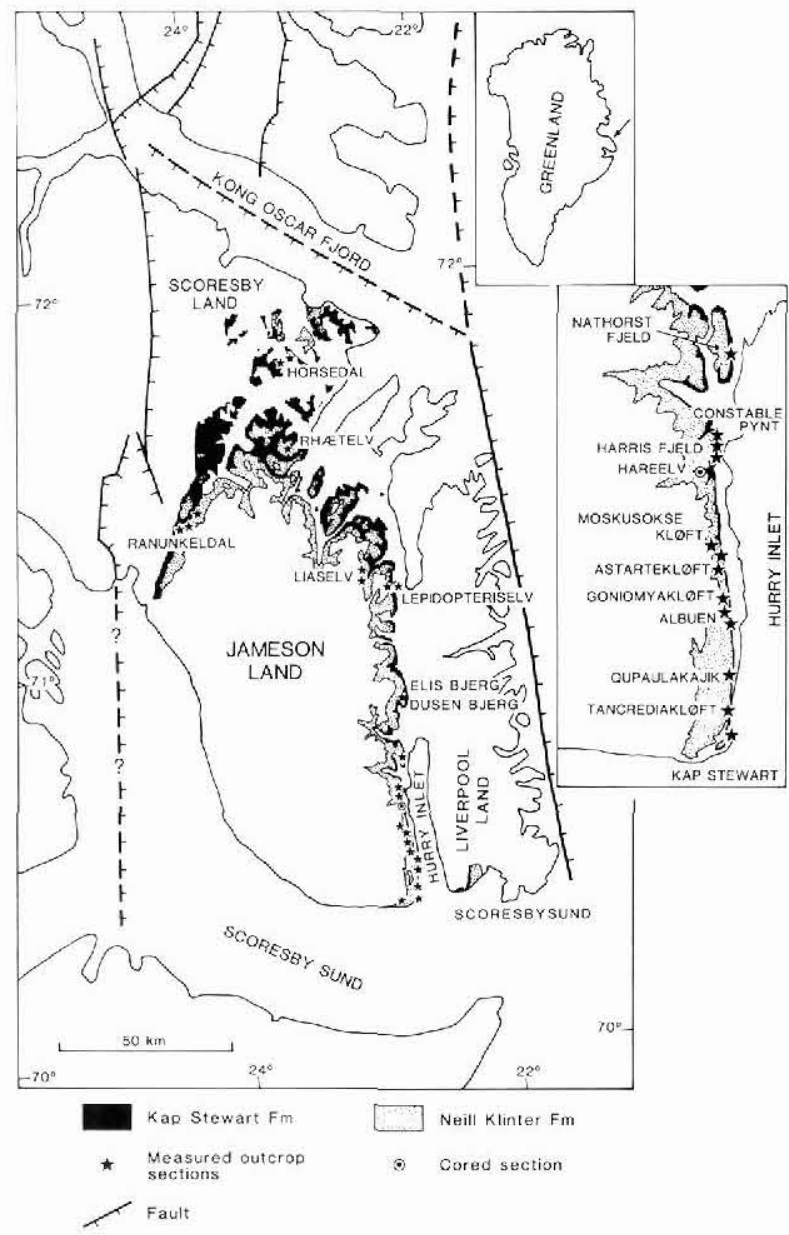

Fig. 1. Map of Jameson Land showing outcrops of the Kap Stewart and Neill Klinter Formations, the major bounding faults of the Jameson Land basin and location of studied sections. Inset map shows southernmost outcrops studied in detail at a larger scale. 


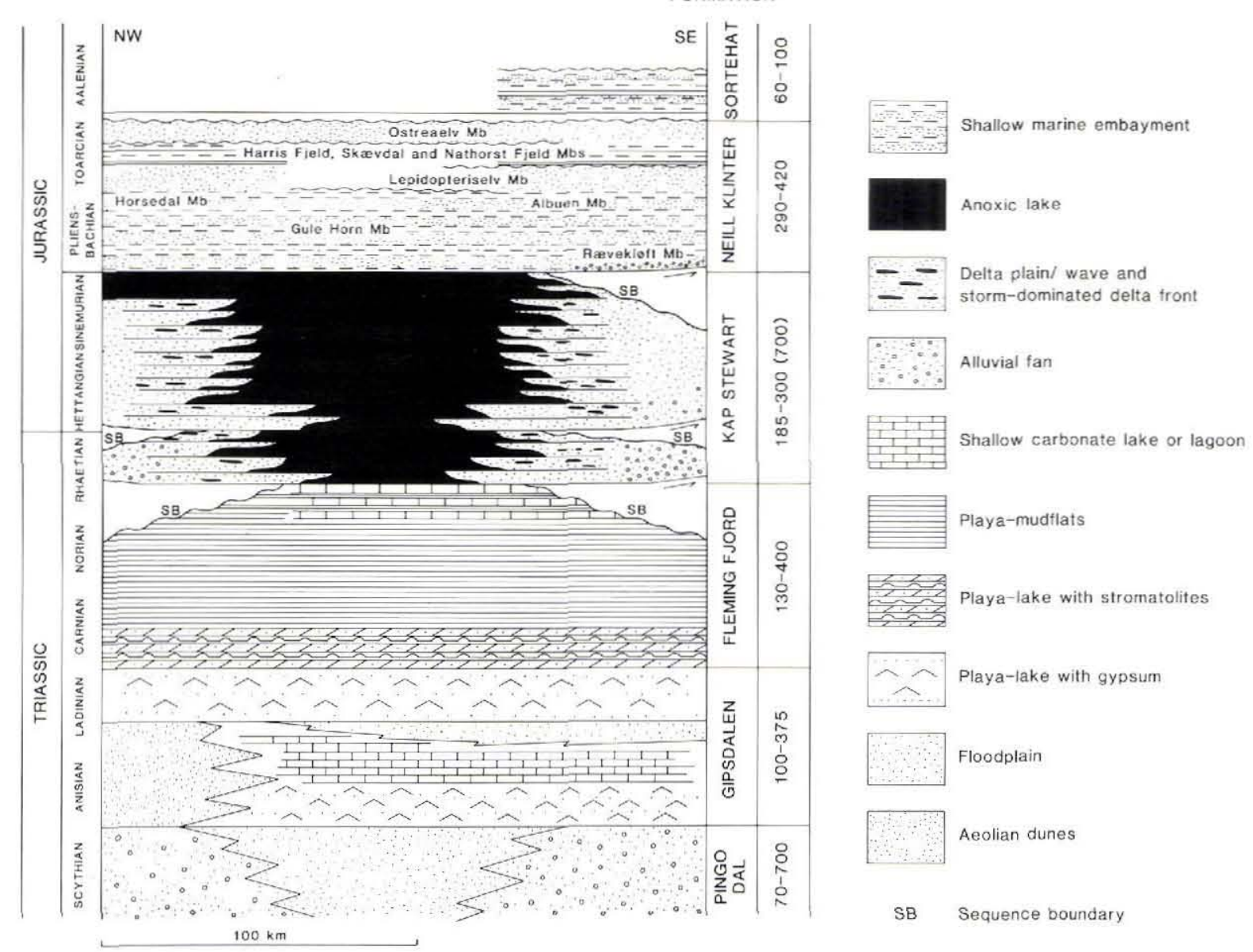

THICKNESS (m) FORMATION

Fig. 2. Schematic chronostratigraphic east-west section through the Triassic - Lower Jurassic of the Jameson Land basin.

climate, were overlain by Middle to Upper Triassic playa mudstones, lacustrine carbonates and floodplain mudstones and sandstones indicative of a more humid climate (Clemmensen, 1980) (Fig. 2). By latest Triassic time the climate had become temperate and humid, as indicated by the disappearance of red beds, evaporites and carbonates, and by the incoming of rootlet horizons, coal beds and perennial lacustrine deposits of the Kap Stewart Formation (Dam, 1991; Dam \& Surlyk, 1992, 1993). This change in climate was accompanied by a relative sea-level rise which, during the Early Jurassic, turned the 'Kap Stewart Formation Lake' into a shallow marine embayment. The marine sediments of the Neill Klinter Formation were the first fully marine sediments deposited in the Jameson Land Basin since the Late Permian - Early Triassic. The long-term climatic control on sedimentation was caused by a gradual northwards drift of the Laurasian continent (Smith et al., 1981).

\section{Kap Stewart Formation - forced regressions in a wave- and storm-dominated anoxic lake}

During Rhaetian-Sinemurian time the site of the Jameson Land Basin was a large, hydrologically closed, wave- and storm-dominated lake (Fig. 3A). The deposits of this lake consist of alternating black organic-rich unfossiliferous mudstones and sheet sandstones and make up the Kap Stewart Formation (Dam \& Christiansen, 1990; Dam, 1991; Dam \& Surlyk, 1992, 1993) (Fig. 4). Anoxic conditions prevailed at the bottom of the lake during deposition of the mudstones, and the water column was probably stratified. The mudstones have an organic carbon content of up to $10 \%$ and hydrogen index values up to 700 . The mudstone intervals are up to $10 \mathrm{~m}$ in thickness and have an areal extent that exceeds $12000 \mathrm{~km}^{2}$ (Dam \& Christiansen, 1990). The sandstones were deposited by progradation of wave- 

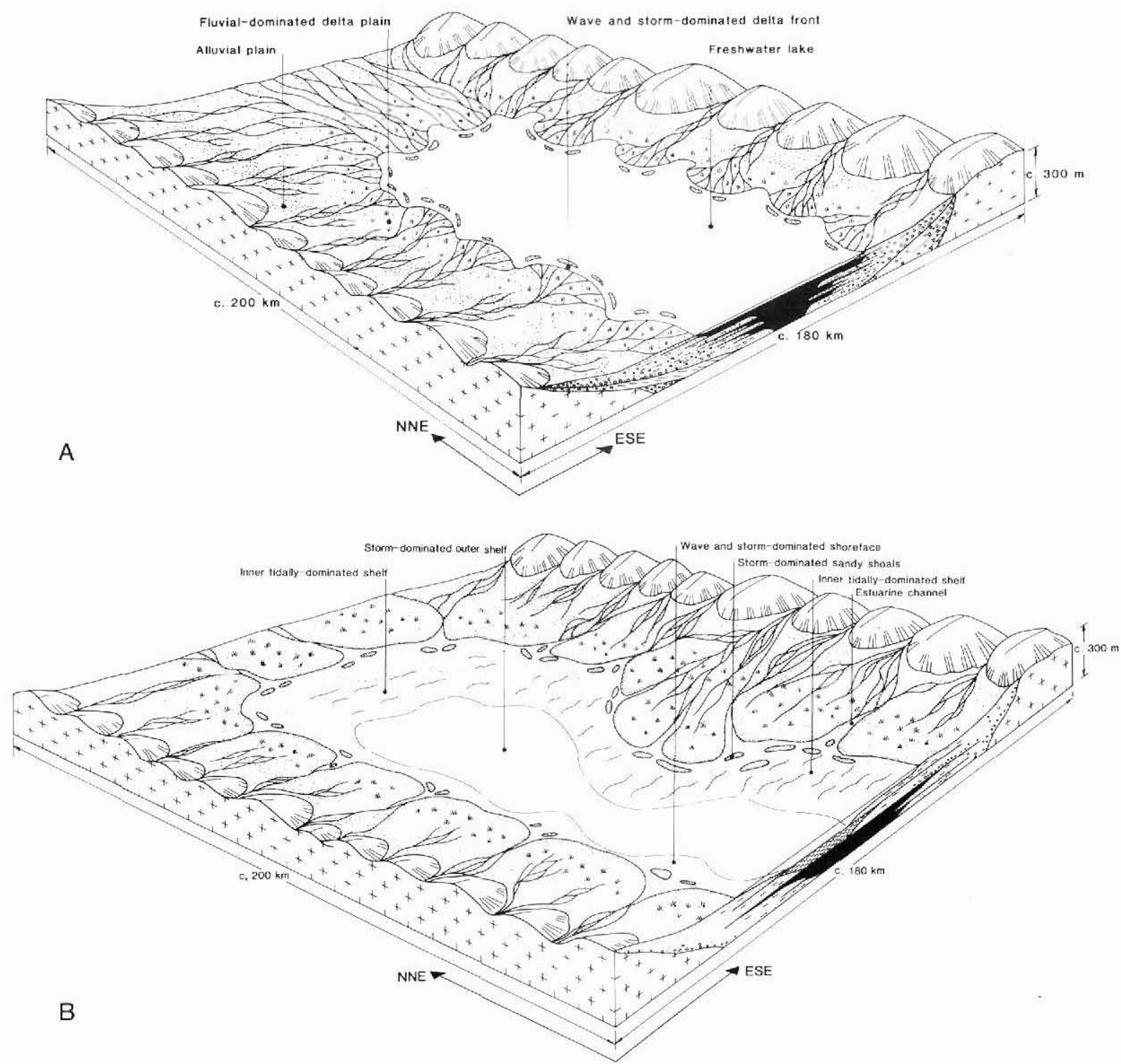

Fig. 3. Palaeogeographic reconstruction of the Jameson Land basin during A, Sinemurian time ('Kap Stewart Formation Lake'), and $\mathrm{B}$, during Pliensbachian time (Neill Klinter Formation marine embayment).

and storm-dominated deltas at water depths of less than $15 \mathrm{~m}$. Sequence stratigraphic interpretation suggests that the mudstones were deposited during periods of rising and very high stands of lake level, while progradation of the deltaic sheet sandstones took place during forced regressions caused by significant falls in lake level. Analysis of the succession shows that the lake underwent a large number of fairly high amplitude changes in water-level, probably caused by climatic fluctuations (Fig. 5A). The high-order cycles can be grouped into several long-period cycles that coincide with major fluctuations in published eustatic sea-level curves (Fig. 5B). This similarity suggests a causal link between eustasy and long-period variations in the lake (Dam \& Surlyk, 1992, 1993).

The Kap Stewart Formation represents one of the few ancient examples of deposits of a large wave- and stormdominated lake, and this study may provide the first documented case of repeated well-developed lacustrine forced regressions. The high-resolution sequence stratigraphic analysis of the lacustrine Kap Stewart Formation has also demonstrated a hitherto unrecognised stratigraphic play type, with organic-rich lacustrine Type I source rocks supplying interbedded deltaic sheet sandstones (Dam \& Surlyk, 1992, 1993; Surlyk et al. . in press). The correct identification of the sequence strati- 


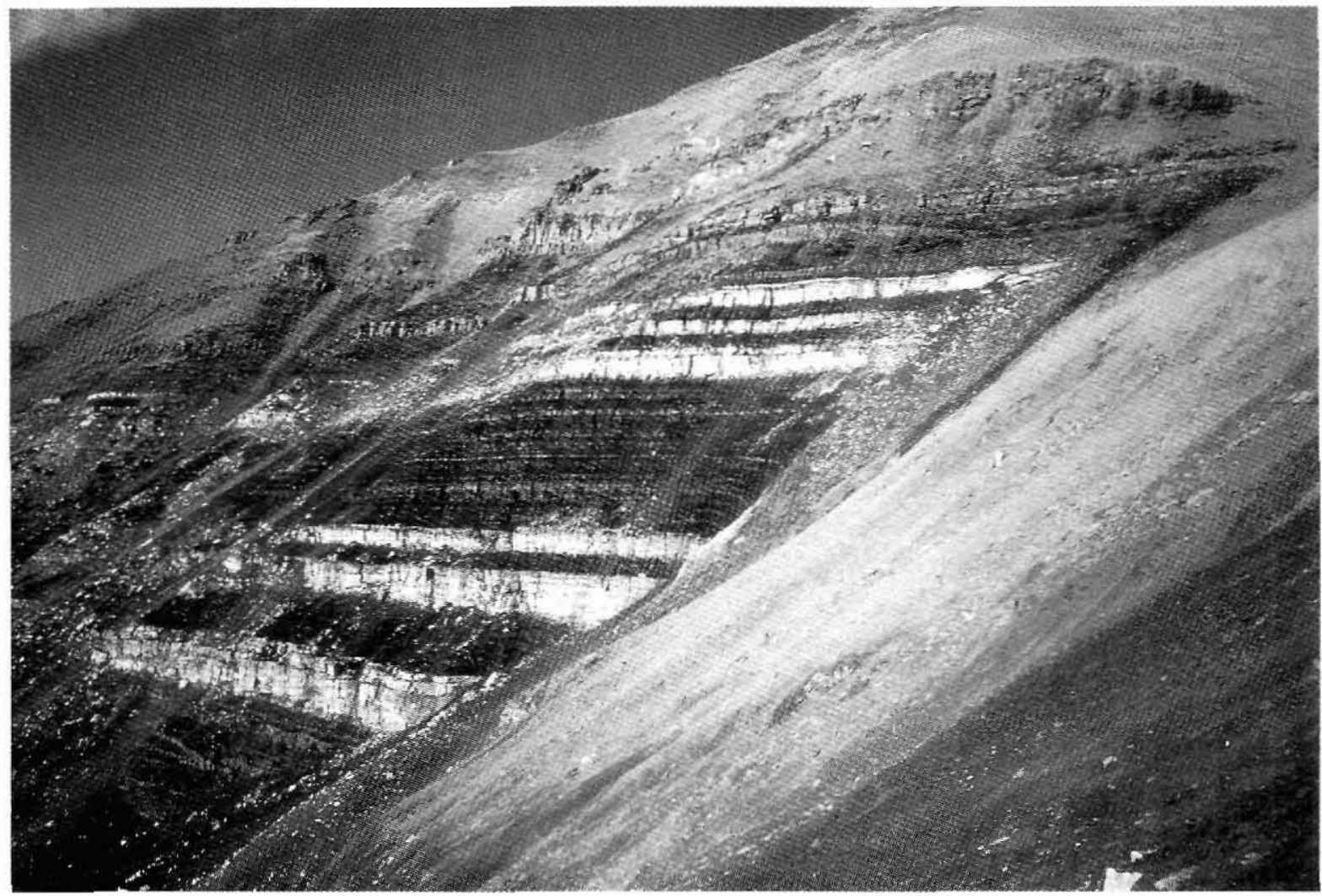

Fig. 4. Alternating organic-rich open lacustrine mudstones and delta front sheet sandstones, The sheet sandstones were deposited during forced regressions and can be followed laterally for several kilometres with only very small changes in thickness. The middle black mudstone is $30 \mathrm{~m}$ thick. From Rhætelv in northern Jameson Land.

graphic elements in this formation also allows prediction of this play type in other settings. Thus, the model proposed may have important implications, especially for the mid-Norwegian shelf, and the possible existence of similar play types in the equivalent Åre Formation on the Norwegian shelf may justify investigation.

\section{Neill Klinter Formation - depositional evolution and stratigraphy of a Lower Jurassic marine embayment succession}

During the Early Pliensbachian the 'Kap Stewart Formation Lake' was transgressed by the sea, and a shallow marine embayment was established in the Jameson Land Basin. This rise in sea-level took place after a sea-level fall sometime during the Sinemurian, which led to erosion along the basin margins (Dam, 1991; Surlyk, 1991). The rise is represented by coastal onlap and marine inundation of the 'Kap Stewart Formation Lake', and is coincident with the acme of a long-term eustatic sea-level rise during the Early Jurassic.
During deposition of the Pliensbachian Ravekløft and Gule Horn Members of the Neill Klinter Formation, the dominant mode of transport was via ebb-dominated estuarine channels into extensive subtidal dune fields (Fig. 3B). The dune fields passed basinwards into restricted, storm-dominated and bioturbated shelf environments. The dune fields were driven by wind and coast-parallel tidal currents. The two members display a series of possibly basin-wide, shallowing-upward successions. These successions formed mainly by progradation of estuarine channels and subtidal sand sheets across restricted, storm-dominated and bioturbated shelf erivironments. Their possible basin-wide nature suggests that the shallowing upward cycles were controlled mainly by regional sea-level changes. Integrated sedimentological and sequence stratigraphic studies indicate that progradation was initiated when sea-level highstand was reached. Sea-level fall resulted in a decrease in accommodation space, and estuarine channels were cut into the underlying deposits. The two members are interpreted as an aggradational to slightly retrograda- 
Fig. 5. A: Kap Stewart Formation lake-level curve (thin line) constructed on the basis of sequence-stratigraphic interpretation of detailed measured vertical sections covering the complete thickness of the formation (expansion shows example of part of the section with lake-level interpretation at the right). The thin line curve at the left shows numerous, closely spaced, probably climatically controlled fluctuations. Heavy-line curve at the left is a smoothed version of the thin-line curve. It shows longterm variations in Kap Stewart Formation Lake level. OL open lacustrine: WLS - waveworked lower shoreface; WUS wave-worked upper shoreface; TL - terminal lobe; DC - distributary channel; SB - sequence boundary; RS - ravinement surface; LST - lowstand systems tract; TST - transgressive systems tract; HST - highstand systems tract. B: Long period 'Kap Stewart Formation Lake' lakelevel curve compared to eustatic sea-level curves of Hallam (1988) and Haq et al. (1988). The similarity of the curves suggests a causal link between long-period eustasy and lake level in the 'Kap Stewart Formation Lake'. After Dam \& Surlyk (1992).
A
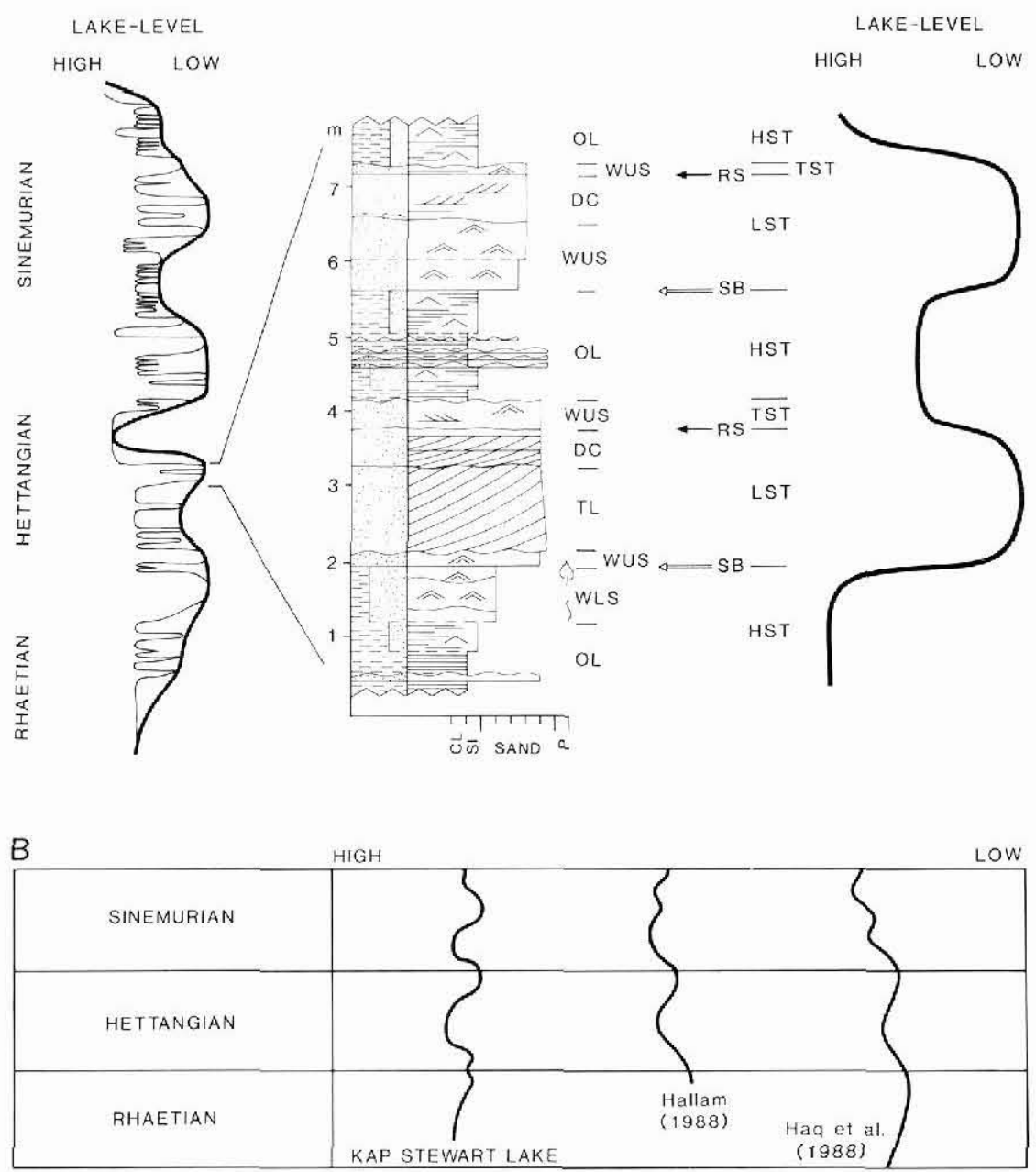

tional parasequence set where the overall rate of sediment input equalled the rate of accommodation (Dam, 1991; Surlyk, 1991).

The Toarcian-Aalenian members of the Neill Klinter Formation and the overlying Sortehat Formation consist of two major basin-wide sheets of shoreface sandstones separated by offshore bioturbated and restricted mudstones (Fig. 2). Sedimentation of the sandstones took place during sea-level rise and highstand. Sand sheets were eroded during sea-level fall and became locally glauconitised and burrowed during succeeding rise. The sea-level rises pushed sedimentation far inshore and omission surfaces were slowly covered by bioturbated and restricted shelf mudstones.

The Neill Klinter Formation contains a diverse assemblage of well-preserved trace fossils, and detailed studies have been undertaken (Dam, 1990a, b). Thirty-- four ichnotaxa are distributed among 11 different ichnocoenoses and include four new ichnospecies. The ichnocoenoses have been interpreted in the light of their trophic and ethological properties and show a strong correlation with the sedimentary environments.

\section{Sequence stratigraphic analysis}

Sequence stratigraphic analysis of the Upper Triassic - Lower Jurassic of East Greenland suggests that a basal Type 1 sequence boundary separates the Kap Stewart Formation from the red beds below (Dam \& Surlyk, 1993). The lower part of the Kap Stewart Formation includes a lower lowstand systems tract topped by a maximum flooding surface and overlain by a transgressive systems tract. A major hiatus, marked by a dramatic change in macroflora and palynology (Harris, 1937; 
Pedersen \& Lund, 1980), separates the lower and upper parts of the Kap Stewart Formation and is interpreted as a Type 2 sequence boundary (Dam \& Surlyk, 1993).

A basal Type 1 sequence boundary separates the Kap Stewart and Neill Klinter Formations. The Neill Klinter Formation includes a Pliensbachian-Toarcian transgressive systems tract composed of an overall aggradational parasequence set overlain by an uppermost Toarcian Aalenian highstand systems tract (Surlyk, 1991). On the basis of the sequence stratigraphic analysis it has been possible to construct a sea-level curve for both the Late Triassic and Early Jurassic (Surlyk, 1990; Dam, 1991; Dam \& Surlyk, 1992, 1993). This curve shows an overall positive correlation with the eustatic curve of Hallam (1988) and Haq et al. (1988), with major sea-level rises at the Rhaetian-Hettangian and Hettangian-Sinemurian boundaries, the Late Sinemurian, Early Pliensbachian, Late Pliensbachian, and two major rises in the Toarcian.

Acknowledgements. The project was supported by BP Exploration Company Ltd., London, with part of the project arranged as a Ph.D. project at the University of Copenhagen, supervised by Professor Finn Surlyk, University of Copenhagen. A sequence stratigraphic extension of the project was carried out in co-operation with Finn Surlyk, with support from Conoco Norway Inc.

\section{References}

Christiansen, F. G., Marcussen, C., Larsen, H. C., Stemmerik, L., Dam, G. \& Piasecki, S. 1991: Petroleum potential of Jameson Land, East Greenland. Exploration Report, Grønlands Geologiske Unders $\emptyset$ gelse, 11 enclosures.

Clemmensen, L. B. 1980: Triassic rift sedimentation and palaeogeography of central East Greenland. Bull. Grønlands geol. Unders. 136, $72 \mathrm{pp}$.

Dam, G. 1988: Sedimentological studies of the fluviatile shallow marine Upper Triassic to Lower Jurassic succession in Jameson Land, East Greenland. Rapp. Gronlands geol. Unders. 140, 76-79.

Dam, G. 1989: Sedimentological studies of the Upper Triassic to Lower Jurassic succession in the Jameson Land Basin, central East Greenland. Rapp. Grønlands geol. Unders. 145, 75-79.

Dam, G. 1990a: Taxonomy of trace fossils from the shallow marine Lower Jurassic Neill Klinter Formation, East Greenland. Bull. geol. Soc. Denmark 38, 119-144.

Dam, G. 1990b: Paleoenvironmental significance of trace fossils from the shallow marine Lower Jurassic Neill Klinter Formation, East Greenland. Palaeogeogr. Palaeoclimat. Palaeoecol. 79, 221-248.

Dam, G. 1991: A sedimentological analysis of the continental and shallow marine Upper Triassic to Lower Jurassic succession in Jameson land, East Greenland. Unpubl. Ph.D. thesis. University of Copenhagen. 244 pp., 6 enclosures.
Dam, G. \& Christiansen, F. G. 1990: Organic geochemistry and source potential of the lacustrine shales of the Late Triassic - Early Jurassic Kap Stewart Formation, East Greenland. Marine Petrol. Geol. 7, 428-443.

Dam, G. \& Surlyk, F. 1992: Forced regressions in a large waveand storm-dominated anoxic lake, Rhaetian-Sinemurian Kap Stewart Formation, East Greenland. Geology 20, 749752.

Dam, G. \& Surlyk, F. 1993: Cyclic sedimentation in a large wave- and storm-dominated anoxic lake; Kap Stewart Formation (Rhaetian-Sinemurian), Jameson Land, East Greenland. In Posamentier, H. W., Summerhayes, D. P., Haq, B. U. \& Allen, G. P. (ed.) Sequence stratigraphy and facies associations. Int. Ass. Sediment. Spec. Publ. 18, 419-448.

Hallam, A. 1988: A reevaluation of Jurassic eustacy in the light of new data and the revised Exxon curve. In Wilgus, C. K., Hastings, C. A., Kendall, C. G. St. C., Posamentier, H. W., Ross, C. A. \& Van Wagoner, J. C. (ed.) Sea-level changes - an integrated approach. Soc. Econ. Paleontol. Mineral. Spec. Publs 42, 261-273.

Haq, B. U., Hardenbol, J. \& Vail, P. R. 1988: Mesozoic and Cenozoic chronostratigraphy and cycles of sea-level changes. In Wilgus, C. K., Hastings, C. A., Kendall, C. G. St. C., Posamentier, H. W., Ross, C. A. \& Van Wagoner, J. C. (ed.) Sea-level changes - an integrated approach. Soc. Econ. Paleontol. Mineral. Spec. Publs 42, 71-108.

Harris, T. M. 1937: The fossil flora of Scoresby Sound, East Greenland. 5. Stratigraphic relations of the plant beds. Meddr Grønland 112(2), 114 pp.

Pedersen, K. R. \& Lund, J. J. 1980: Palynology of the plantbearing Rhaetian to Hettangian Kap Stewart Formation, Scoresby Sund, East Greenland. Rev. Palaeobot. Palynol. 31, 1-69.

Smith, A. G., Hurley, A.. M. \& Briden, J. C. 1981: Phanerozoic palaeocontinental world maps, 102 pp. Cambridge University Press.

Surlyk, F. 1978: Jurassic basin evolution of East Greenland. Nature, Lond. 274, 130-133.

Surlyk, F. 1990: A Jurassic sea-level curve for East Greenland. Palaeogeogr. Palaeoclimat. Palaeoecol. 78, 71-85.

Surlyk, F. 1991: Sequence stratigraphy of the Jurassic - lowermost Cretaceous of East Greenland. Bull. Am. Ass. Petrol. Geol. 75, 1468-1488.

Surlyk, F., Hurst, J. M., Piasecki, S., Rolle, F., Scholle, P. A., Stemmerik, L.\& Thomsen, E. 1986: The Permian of the western margin of the Greenland Sea - a future exploration target. In Halbouty, M. T. (ed.) Future petroleum provinces of the world. Mem. Am. Ass. Petrol. Geol. 40, 629-659.

Surlyk, F., Noe-Nygaard, N. \& Dam, G. in press: High and low resolution sequence stratigraphy in lithological prediction - examples from the Mesozoic around the northern North Atlantic. In Spencer, A. M. (ed.) Proceedings of the 4th conference on the petroleum geology of North West Europe.

G. D., Geological Survey of Greenland, Copenhagen. 